Proc. Indian Acad. Sci. (Earth Planet. Sci.), Vol. 94, No. 1, March 1985, pp. 13-27.

(C) Printed in India.

\title{
Hydrography and circulation off the Antarctica in the Indian Ocean region
}

\author{
G S SHARMA AND BASIL MATHEW* \\ School of Marine Sciences, University of Cochin, Cochin 682016, India \\ *Present address: Naval Physical and Oceanographic Laboratory, Cochin 682 004, India
}

MS received 23 May 1984; revised 9 November 1984

\begin{abstract}
The hydrography and circulation pattern off Antarctica in the Indian Ocean region are studied using vertical sections of temperature, salinity and oxyty approximately along $20^{\circ} \mathrm{E}, 77^{\circ} \mathrm{E}$ and $90^{\circ} \mathrm{E}$, and the dynamic topography of the sea surface with reference to $1000 \mathrm{db}$. Based on the oceanographic characteristics, the whole region under study can be divided into three zones, the extreme ends being characterised by the frontal structure. The dicothermal layer is conspicuous during summer south of $50^{\circ} \mathrm{S}$. The surface flow around Antarctica is mainly zonal. The East Wind Drift, found as a narrow westward flow near Antarctica, is observed at a lower latitude in the eastern Indian Ocean where the land extends northword. Contrary to expectation there is evidence of a west ward flowing surface current at about $35^{\circ} \mathrm{S}$ between $45^{\circ} \mathrm{E}$ and $65^{\circ} \mathrm{E}$.
\end{abstract}

Keywords. Hydrography; circulation pattern; Antarctica; Indian Ocean; meridional section.

\section{Introduction}

The poles and the neighbouring oceanic regions act as the sinks of the heat budget of the oceans and atmosphere. The oceanic and atmospheric circulations, to a large extent, depend on the conditions in these regions. Hence, it is imperative to know the conditions of the polar regions to understand the oceanic and atmospheric circulations.

Of the two poles, the south pole plays a major role as it is connected with the three major oceans of the world while the north pole has no connection with the Indian Ocean. Due to this land-locked nature on its northern boundary, the oceanic circulation in the North Indian Ocean and the atmospheric circulation over the intertropical Indian Ocean deviate very much from those of the other two major oceans. Further, $45 \%$ of the coastline of Antarctica is bounded by floating glacial ice sheets known as ice shelves. Thus, an understanding of their effect on the surrounding ocean seems to be necessary for establishing mass and heat balances for the waters around Antarctica.

In view of the significance of the Antarctic region in controlling the oceanic and atmospheric circulation, concentrated efforts have been made to study this region during the last decade. Most of these efforts are concerned with the oceanography off Antarctica in the regions of the Pacific and Atlantic.

Our basic understanding about the physical oceanography of the southern oceans came mainly from the German south polar expedition 1901-1902 (Meinardus 1923), R.R.S. Discovery II Cruise (Deacon 1933, 1937; Mackintosh 1946), Norwegian Antarctica Expedition 1927-1928 (Mosby 1934) and B.A.N.Z. Antarctica Research Expedition 1921-1931 (Sverdrup 1940). Further knowledge was gained through 
subsequent studies (Gordon 1967, 1971a, b, 1972, 1975, 1978, 1981; Gordon and Tchernia 1972; Gordon et al 1977a, b, 1978; Houtman 1964; Heath et al 1978; Georgi 1978, 1979 , 1981; Emery 1977; Ivanov 1961; Jacobs and Georgi 1977; Joyce et al 1978, 1981; McGinnes 1974; Molinelli 1981; Nowlin et al 1977; Sciremammano 1979; Sievers and Emery 1978; Whitworth 1980). All these investigations, with the exception of a few, were confined to the regions in the Atlantic and Pacific, and very little is known about the hydrography off Antarctica in the Indian Ocean region. An attempt was therefore made to study the hydrography of the region and the circulation pattern using the oceanographic data already available.

\section{Materials and methods}

The oceanographic data for the present study came from 283 stations covered by various vessels. The details are given in table 1 and the station positions are shown in figure 1. Stations encircled are used for vertical sections.

The in situ temperature at times instead of decreasing increases with depth, particularly in the deeper layers displaying an apparent instability due to pressure effect. To avoid ambiguity the potential temperature is computed using the nomogram prepared by Montgomery and Pollak from Helland-Hansen's formula (HellandHansen 1930).

Three meridional sections of potential temperature, salinity and oxyty are presented in figures $2 \mathrm{a}, \mathrm{b}, \mathrm{c}$ to $4 \mathrm{a}, \mathrm{b}, \mathrm{c}$ approximately along $20^{\circ} \mathrm{E}, 77^{\circ} \mathrm{E}$ and $90^{\circ}$ respectively, to study the hydrography off Antarctica in Indian Ocean. The vertical gradients of the hydrographic properties in the upper layers are very strong while they are weak in the deeper layers. Therefore the depth scale is exaggerated in the upper $400 \mathrm{~m}$ compared to that below.

Table 1. List of stations used for the present study (figure 1)

\begin{tabular}{|c|c|c|c|}
\hline Name of the Vessel & $\begin{array}{c}\text { Symbol } \\
\text { used }\end{array}$ & $\begin{array}{l}\text { No. of } \\
\text { stations }\end{array}$ & Period \\
\hline OB & $\odot$ & 20 & 4 March 1956 to 28 May 1956 \\
\hline OB & $\odot$ & 105 & 14 Jan. 1957 to 19 April 1957 \\
\hline Umitaka Maru & + & 16 & 12 Dec. 1956 to 6 March 1957 \\
\hline Africana & $\square$ & 19 & 3 July 1961 to 15 July 1961 \\
\hline Africana & $\square$ & 13 & 2 June 1962 to $11 \mathrm{July} 1962$ \\
\hline Africana & $\square$ & 7 & 7 April 1963 to 13 April 1963 \\
\hline Argo & $x$ & 5 & 2 Nov. 1962 to 16 Dec. 1962 \\
\hline Fuji & - & 8 & 19 Dec. 1965 to 21 Feb. 1966 \\
\hline Fuji & - & 10 & 25 Dec. 1973 to 24 Feb. 1974 \\
\hline Fuji & - & 3 & 24 Dec. 1974 to 25 Feb. 1975 \\
\hline Akademic Shirshov & $\nabla$ & 24 & 21 Nov. 1970 to 6 Dec. 1970 \\
\hline Akademic Shirshov & $\nabla$ & 9 & 3 July 1970 to 9 July 1970 \\
\hline Fusakaze & $\Delta$ & 8 & 24 Dec. 1971 to 6 April 1972 \\
\hline Eltanin & $\triangle$ & 7 & 28 Feb. 1971 to 15 March 1971 \\
\hline Eltanin & $\Delta$ & 6 & 24 July 1971 to 3 Aug. 1971 \\
\hline Eltanin & $\Delta$ & 13 & 18 Sept. 1971 to 7 Oct. 1971 \\
\hline Eltanin & $\triangle$ & 10 & 27 June 1972 to 6 July 1971 \\
\hline
\end{tabular}




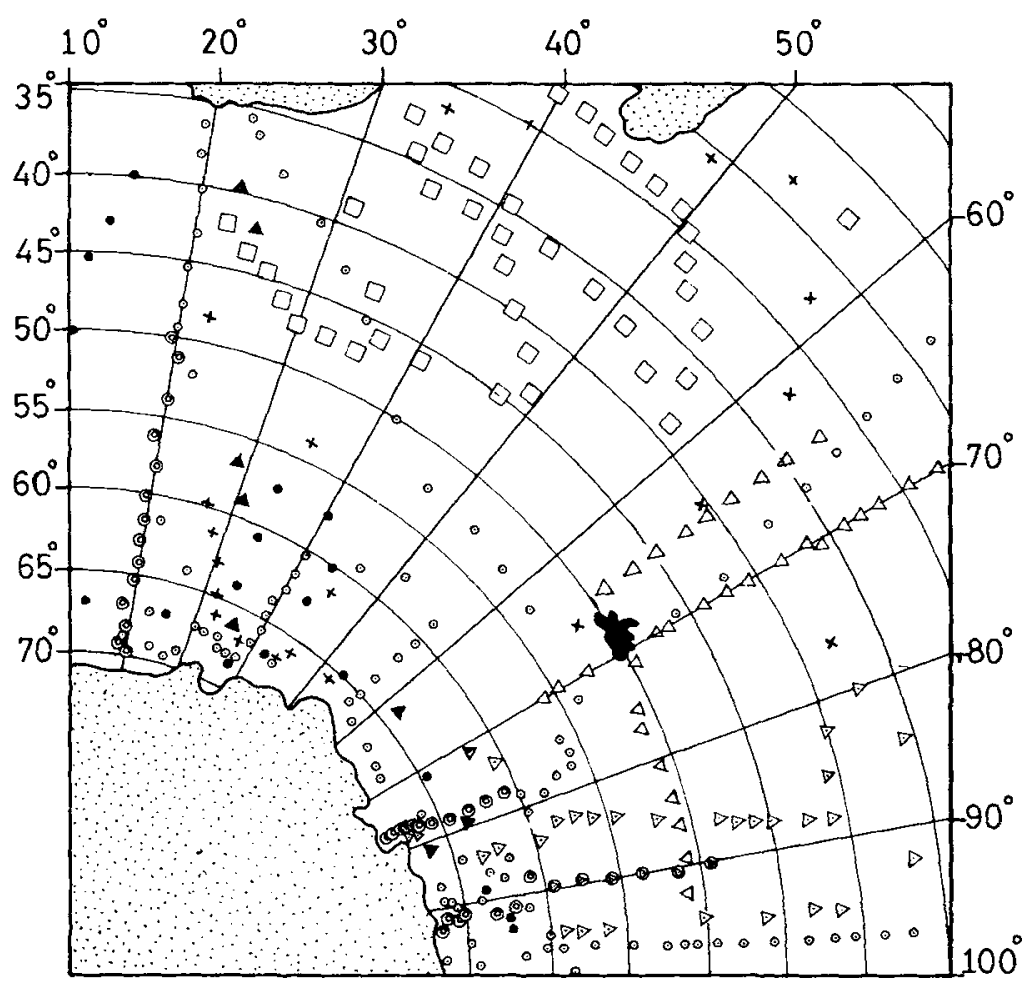

Figure 1. Station positions as in table 1 .

To study the circulation at the surface and subsurface at the depths of 100 and $200 \mathrm{~m}$, dynamic topographic charts with reference to $1000 \mathrm{db}$ surface have been worked out. On examination, the circulation pattern at all these levels is similar except that the horizontal gradients of dynamic height are weak at subsurface depths. Therefore, only the surface circulation through dynamic height is presented in figure 5 .

Deacon (1982) critically discussed the nomenclature used for different zones in the southern oceans and it is obvious that there is diversity in the nomenclature. The intention of this paper is not to go into those details but to adopt our own nomenclature.

\section{Distribution of bydrographic properties}

\subsection{Meridional section along $20^{\circ} \mathrm{E}$}

The distribution of temperature is conspicuously divided into three zones in this section. The southernmost and northernmost regions are marked by meridional temperature gradients. The central zone is conspicuous in its vertical temperature gradients in the upper $200 \mathrm{~m}$. The southernmost region, south of $68^{\circ} \mathrm{S}$ is termed the Polar Front Zone while the region north of $54^{\circ}$ is the Sub-Antarctic Convergence Zone 


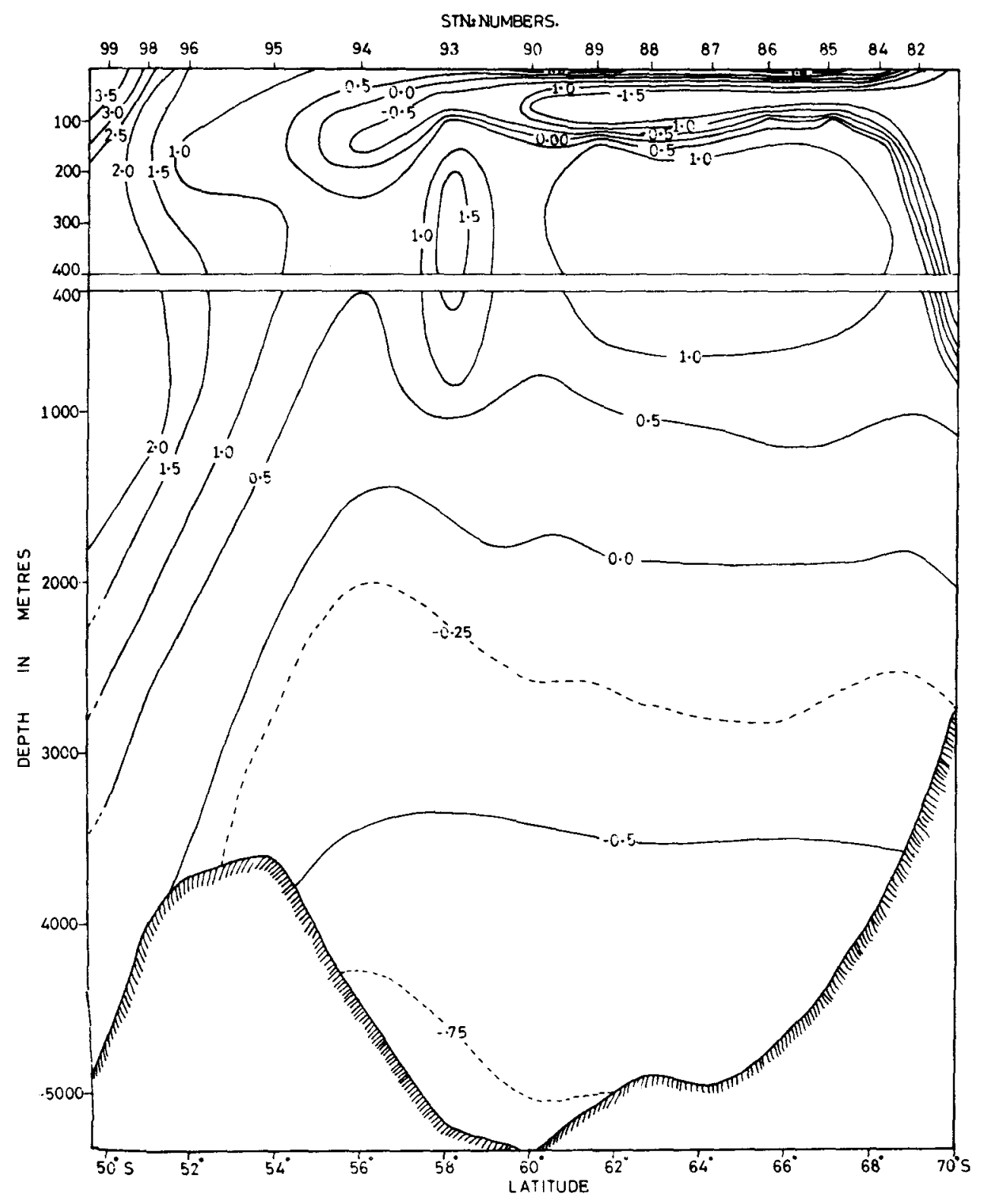

Figure $2(a)$. Vertical section of potential temperature $\left({ }^{\circ} \mathrm{C}\right)$ approximately along $20^{\circ} \mathrm{E}$.

(Polar Front according to Deacon 1982), characterised by frontal structure. While the surface temperature between $52^{\circ} \mathrm{S}$ and $68^{\circ} \mathrm{S}$ ranges from 0.64 to $1.49^{\circ} \mathrm{C}$ only, the temperature difference in both the frontal zones over a horizontal distance of about $2^{\circ}$ latitude is more than $2^{\circ} \mathrm{C}$.

The strong meridional gradient in the temperature in the Polar Front Zone appears to be the consequence of the boundary between the East and West Wind drifts. Within 


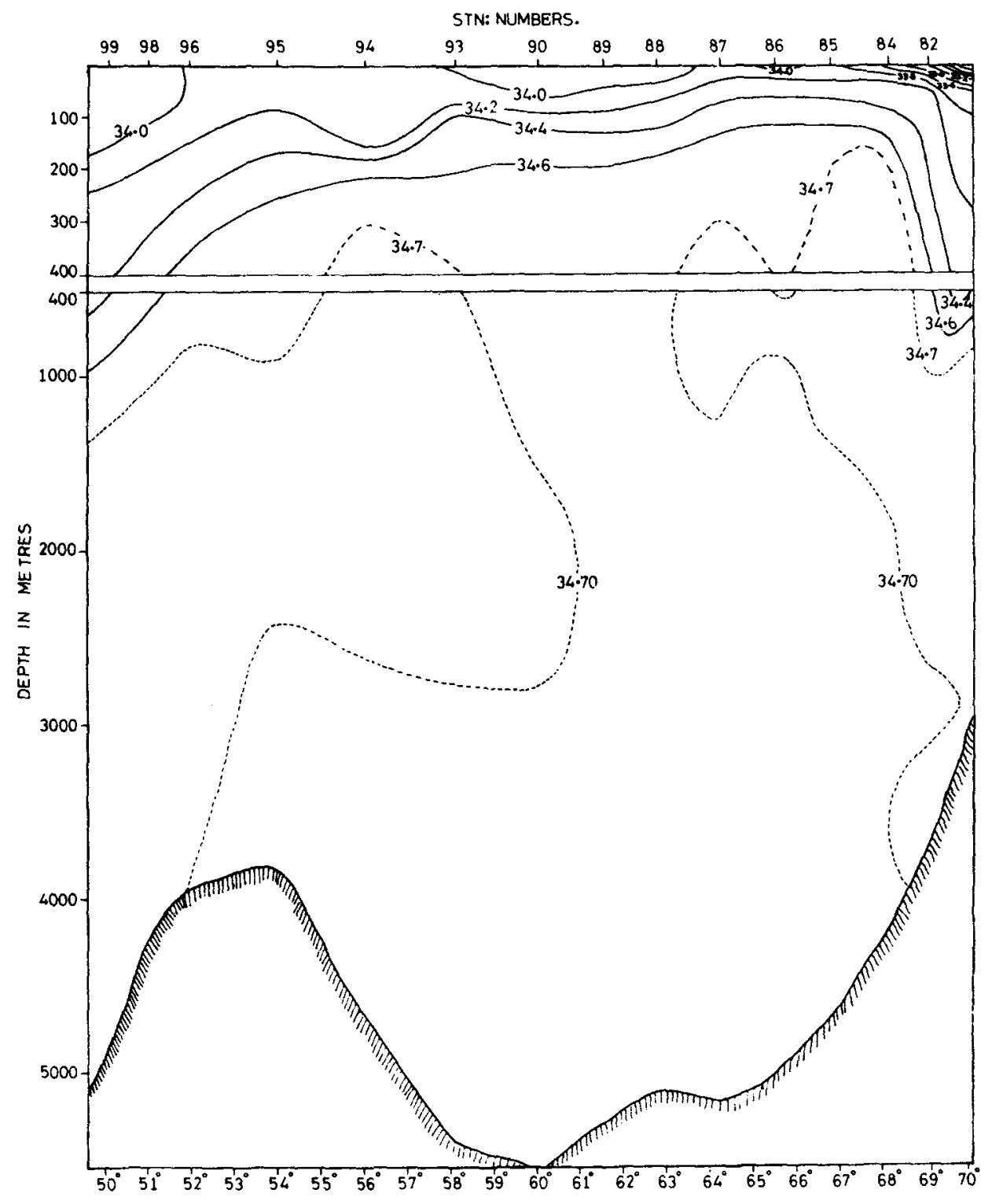

Figare 2(b). Vertical section of salinity $(\%)$ approximately along $20^{\circ} \mathrm{E}$.

the Polar Front Zone the orientation of isotherms, isohalines and isolines of oxyty is almost similar and they indicate the gliding of the subsurface water to deeper layers accompanied by the sliding of the Antarctic Water at the surface. In the central region the temperature decreases with depth attaining the lowest and then increases. From south to north within this zone, the subsurface temperature minimum deepens, decreases in magnitude and finally terminate at about $54^{\circ} \mathrm{S}$.

Inversion below the temperature minimum layer indicates an apparent instability 


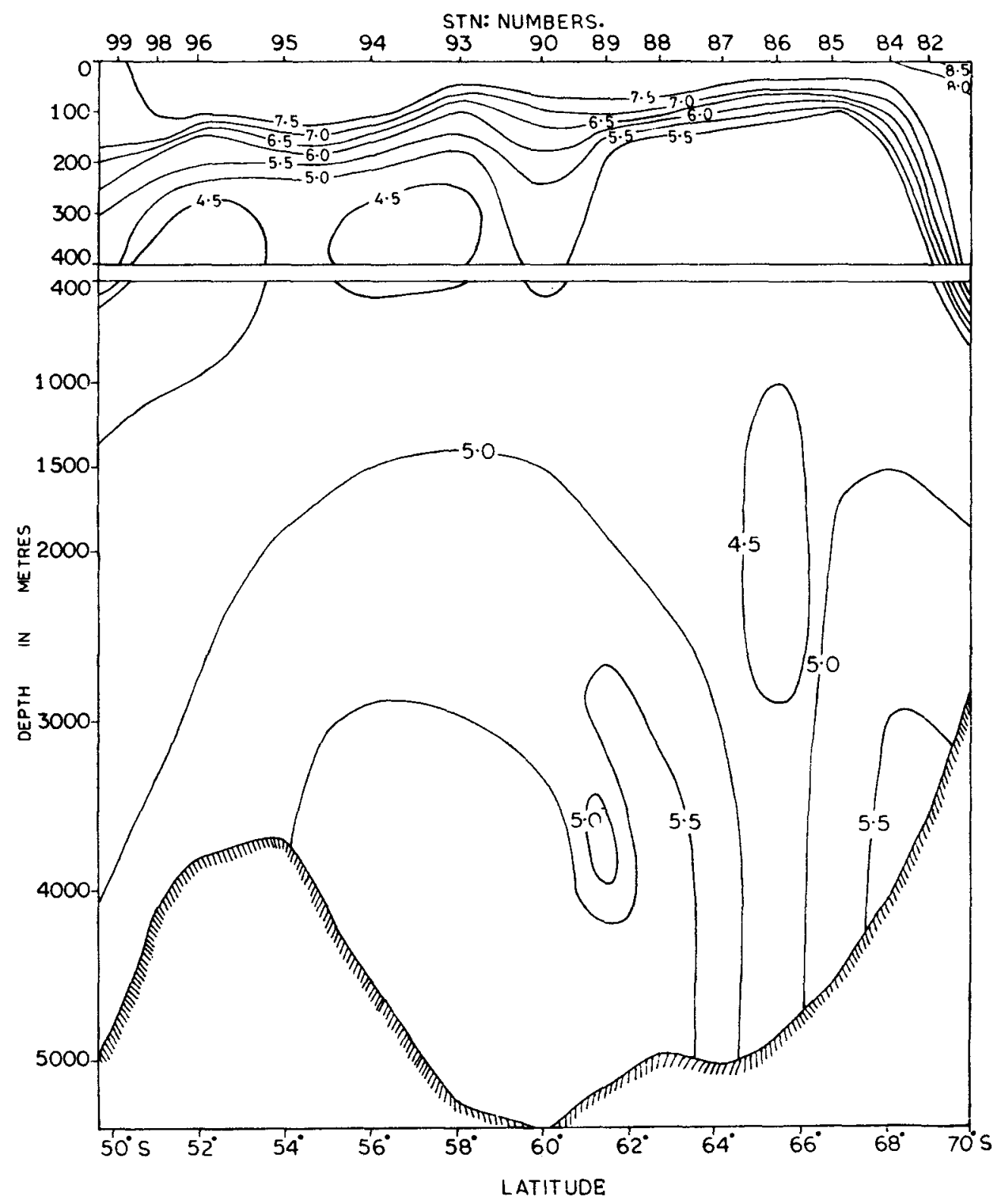

Figure 2(c). Vertical section of oxyty $(\mathrm{ml} / \mathrm{l})$ approximately along $20^{\circ} \mathrm{E}$.

but the effect of the temperature is overcompensated by the increase in salinity to maintain the stability. The waters between 150 and $700 \mathrm{~m}$ record the highest temperature and it is associated with higher salinity and lower oxyty.

In the Antarctic Convergence Zone the meridional gradients extend almost to the bottom. The orientation of the isolines of the properties reveals the sinking of relatively cold surface waters from the south. 
STN: NUMBERS.

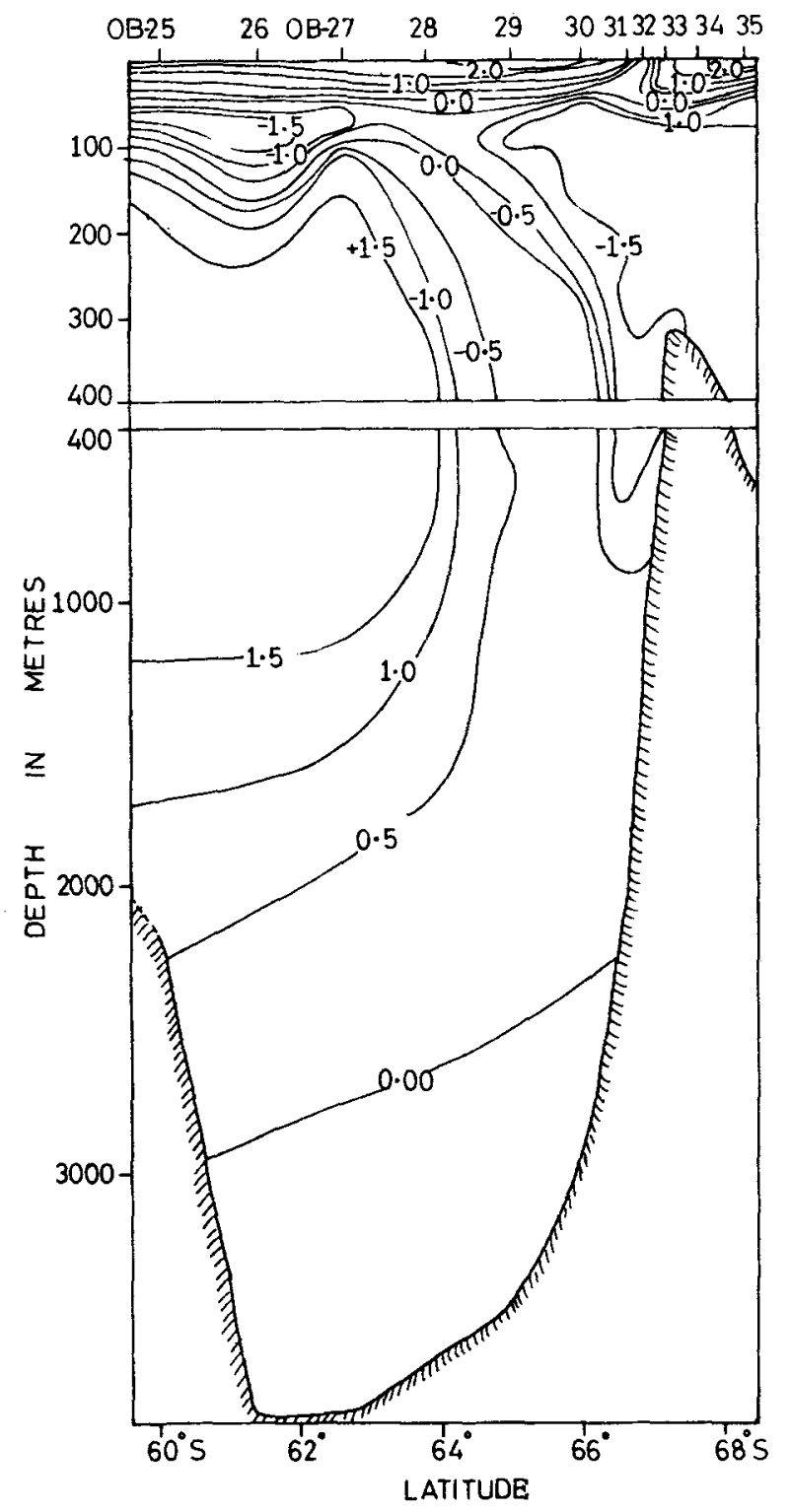

Figure 3(a). Vertical section of potential temperature $\left({ }^{\circ} \mathrm{C}\right)$ approximately along $77^{\circ} \mathrm{E}$.

\subsection{Meridional section along $77^{\circ} \mathrm{E}$}

This section runs across $60^{\circ} \mathrm{S}$ to $68^{\circ} 19^{\prime} \mathrm{S}$. The surface water between $60^{\circ}$ and $65^{\circ} \mathrm{S}$ is almost isothermal south of which the temperature decreases meridionally upto $67^{\circ} \mathrm{S}$ and then increases. The highest temperature of $2.68^{\circ} \mathrm{C}$ recorded at the surface at the southernmost point may perhaps be due to continuous summer heating. The 


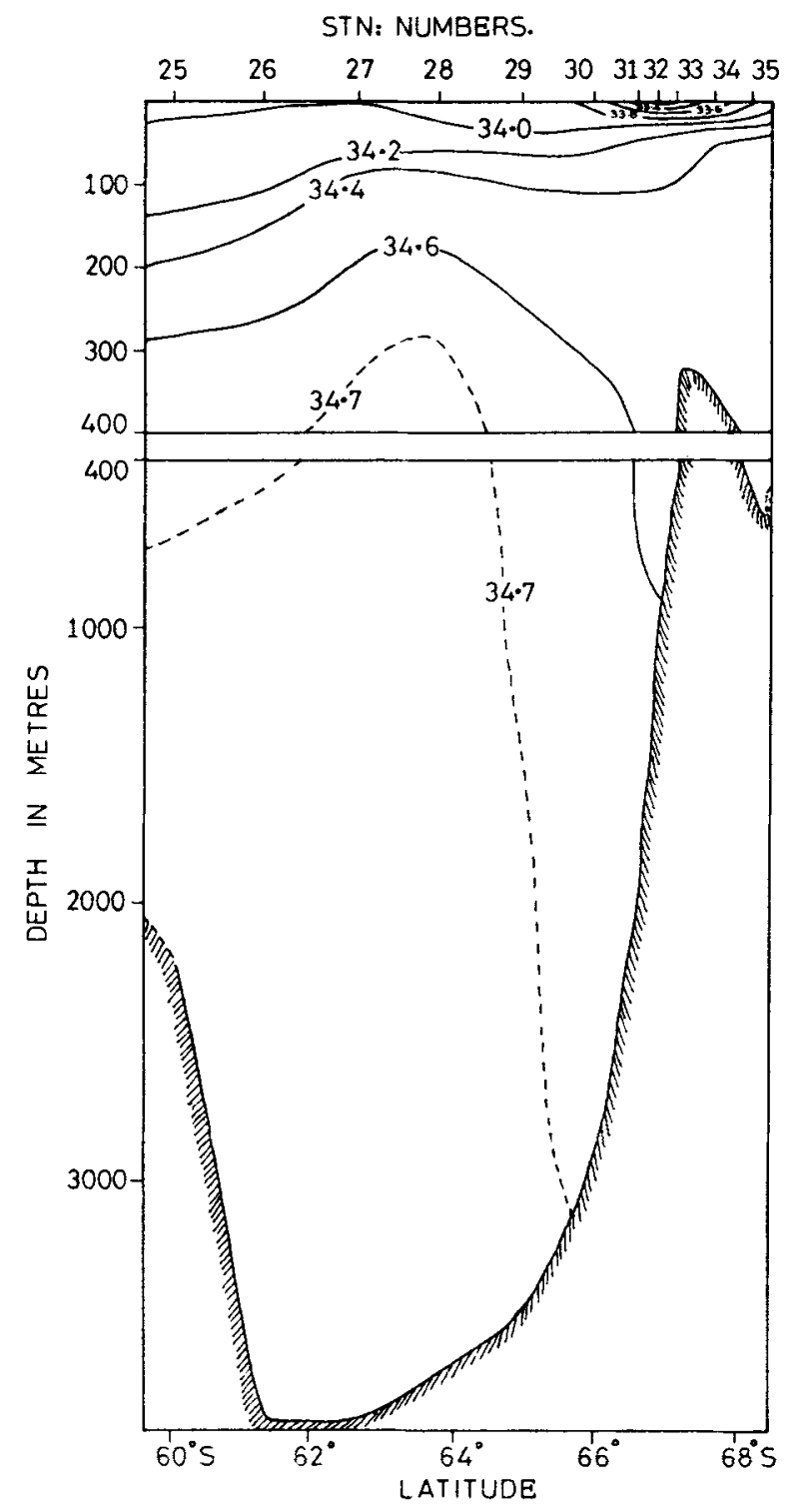

Figure 3(b). Vertical section of salinity $(\%)$ approximately along $77^{\circ} \mathrm{E}$.

temperature minimum layer in the southern region of the section extends from about $50 \mathrm{~m}$ to more than $300 \mathrm{~m}$. The lowest temperature recorded is in a basin in the slope of Antarctica. The coldest water is associated with relatively higher salinity and higher oxyty. This water seems to have been trapped in the basin during the previous winter. It is interesting to note that the orientation of the isolines of temperature and oxyty is almost symmetrical. The thickness of the colder water in the subsurface depths in the northern region is very small unlike in the south. The salinity distribution shows a continuous increase with depth upto the bottom whereas warm and low oxygen water is 
STN: NUMBERS.

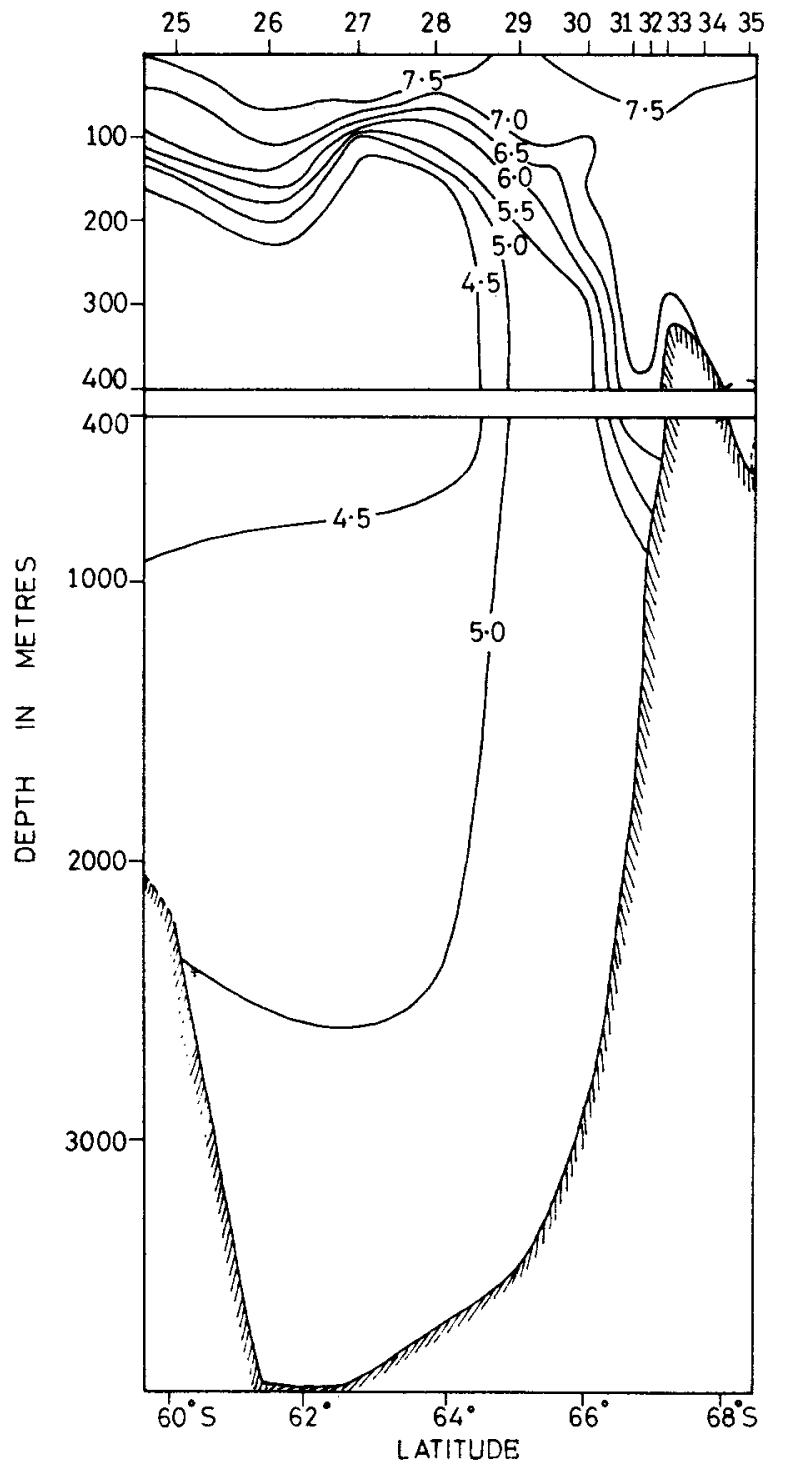

Figure 3(c). Vertical section of oxyty $(\mathrm{ml} / \mathrm{l})$ approximately along $77^{\circ} \mathrm{E}$.

trapped approximately within the depth range of 200 to $1000 \mathrm{~m}$. The deep waters are almost homogenous in character.

\subsection{Meridional section along $90^{\circ} \mathrm{E}$}

This section runs from $48^{\circ} \mathrm{S}$ to $66^{\circ} \mathrm{S}$. It is covered in two seasons. The stations north of $59^{\circ} \mathrm{S}$ were occupied during winter while the southern stations were occupied in 


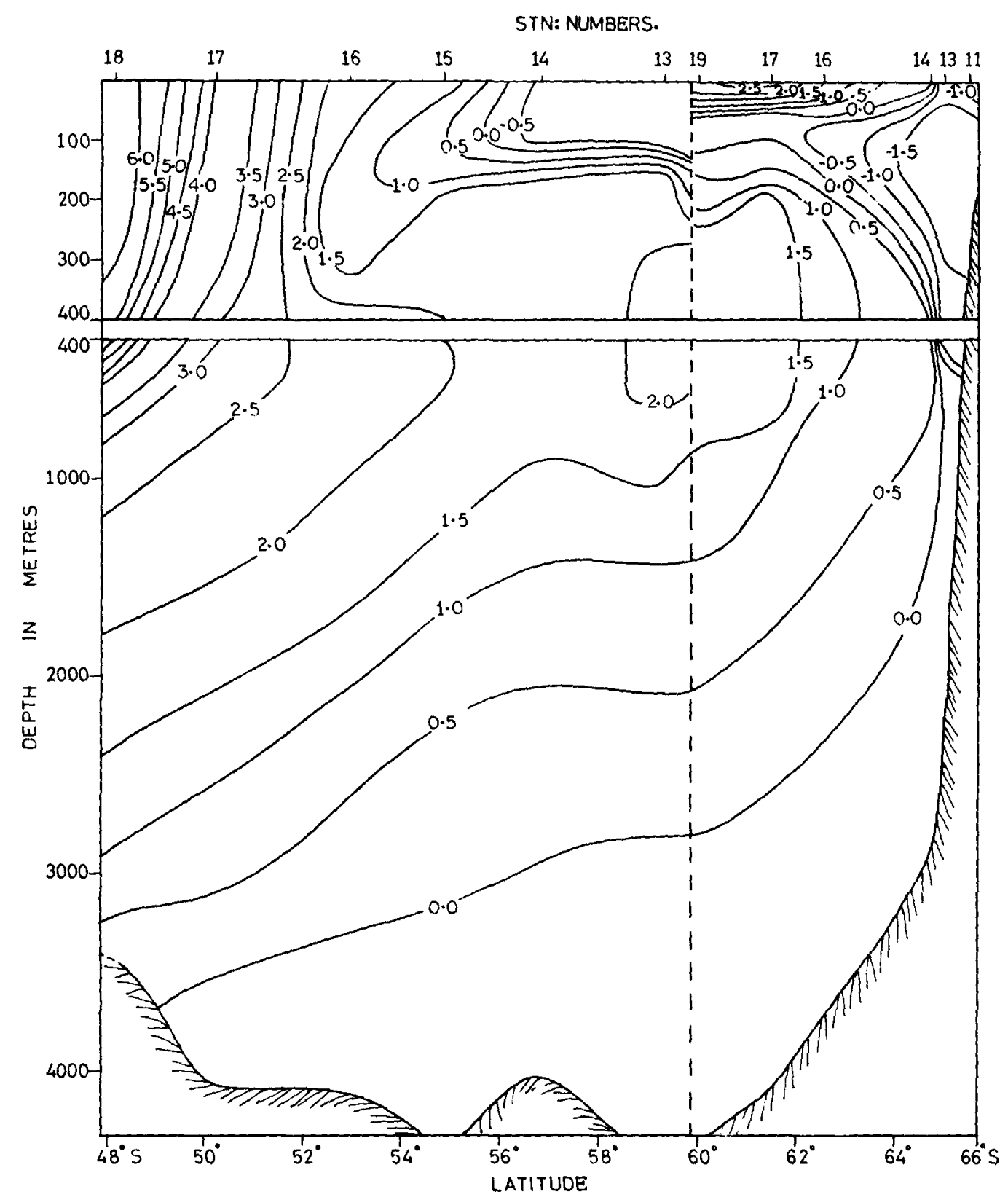

Figure $4(a)$. Vertical section of potential temperature $\left({ }^{\circ} \mathrm{C}\right)$ approximately along $90^{\circ} \mathrm{E}$.

summer. From this section it is evident that the temperature minimum in subsurface depths does not occur in winter but it is a phenomenon associated only with summer. The surface temperature continuously decreases southward and the lowest temperatures might have been recorded near the continental shelf due to lack of radiation for about 6 months. It can also be inferred from this section that during winter, the 


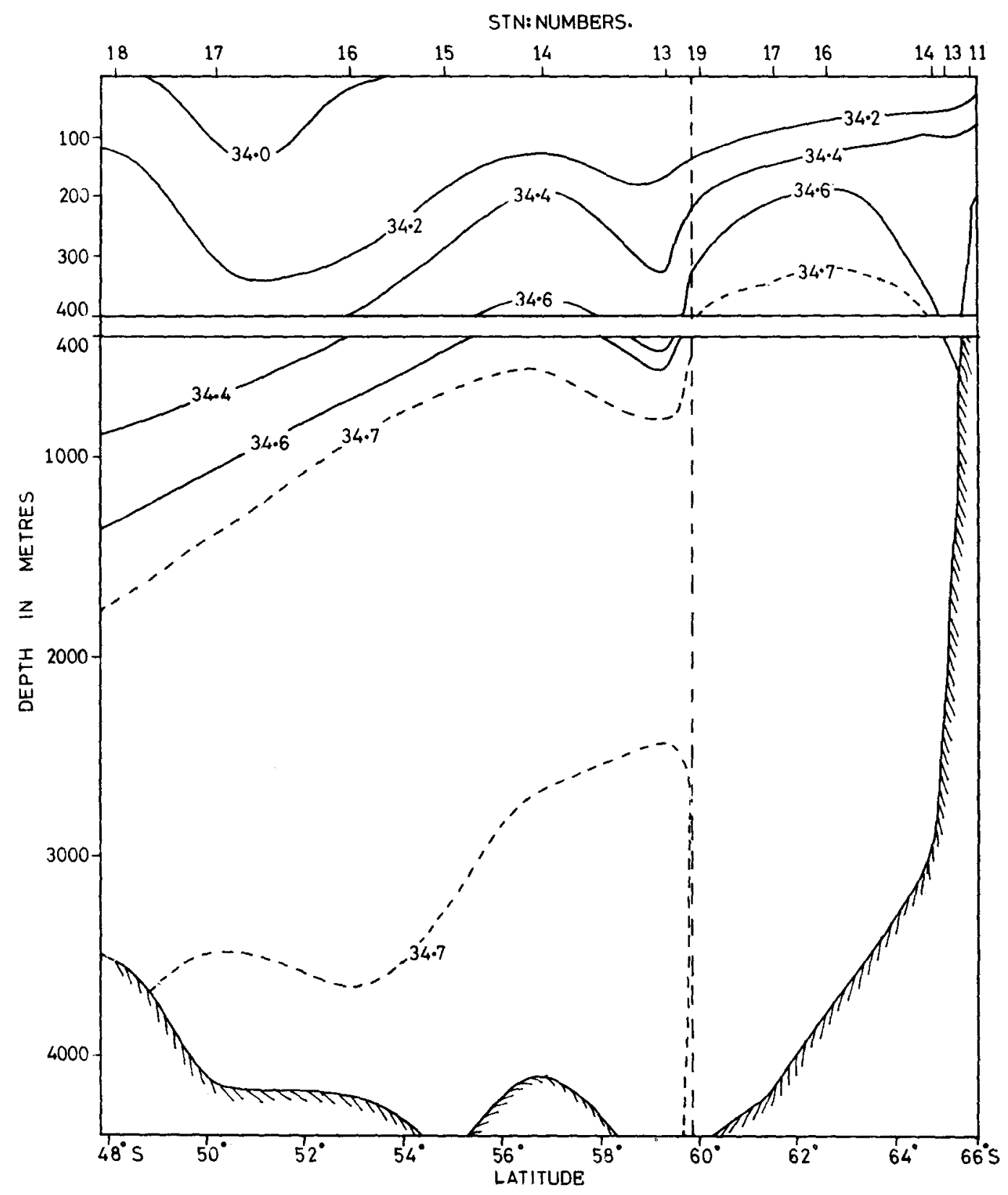

Figare $4(\mathrm{~b})$. Vertical section of salinity $(\%)$ approximately along $90^{\circ} \mathrm{E}$.

Subantarctic Convergence Zone shifts southward and the meridional gradients also strengthen. The thickness of the warmer water in the subsurface depths is much higher in winter compared to that in summer. Within the Polar Front Zone a subsurface maximum in oxygen and a minimum in salinity are seen to extend from the surface layer downward to the north. Surprisingly, the vertical salinity gradient is the least in this 


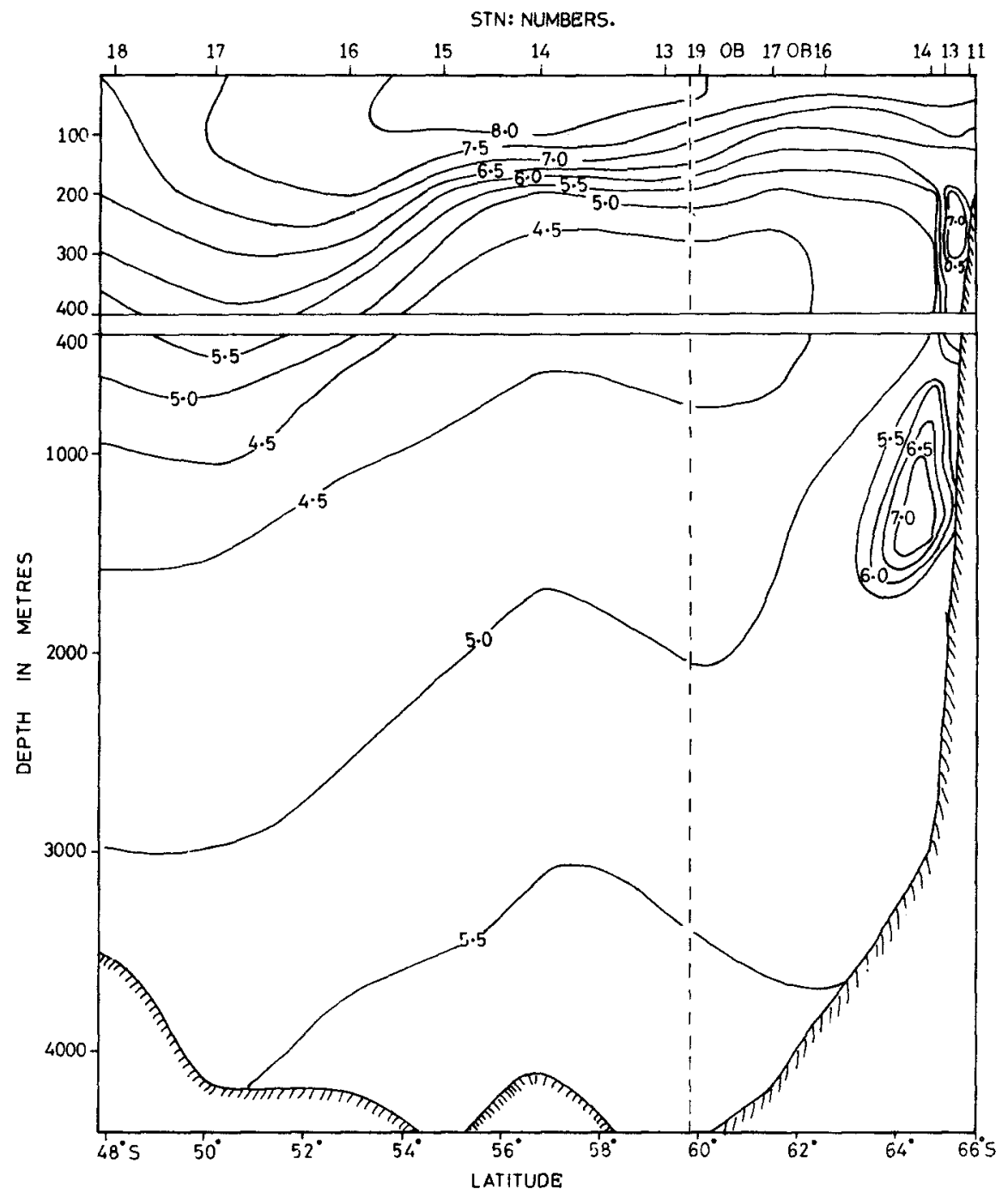

Figure $4(\mathrm{c})$. Vertical section of oxyty $(\mathrm{ml} / \mathrm{l})$ approximately along $90^{\circ} \mathrm{E}$.

section, probably, because of winter convection. During winter the oxygen minimum layer becomes thinner and deeper northward.

\section{Circulation}

Near the Antarctic continent the East Wind Drift is present, north of which the Circumpolar Current is noticed. The Circumpolar Current has northwest to southeast orientation between $50^{\circ} \mathrm{S}$ at $10^{\circ} \mathrm{E}$ and $65^{\circ} \mathrm{S}$ at $70^{\circ} \mathrm{E}$. The northward continuation of the Circumpolar Current in the Indian Ocean region merges with the West Wind Drift. 


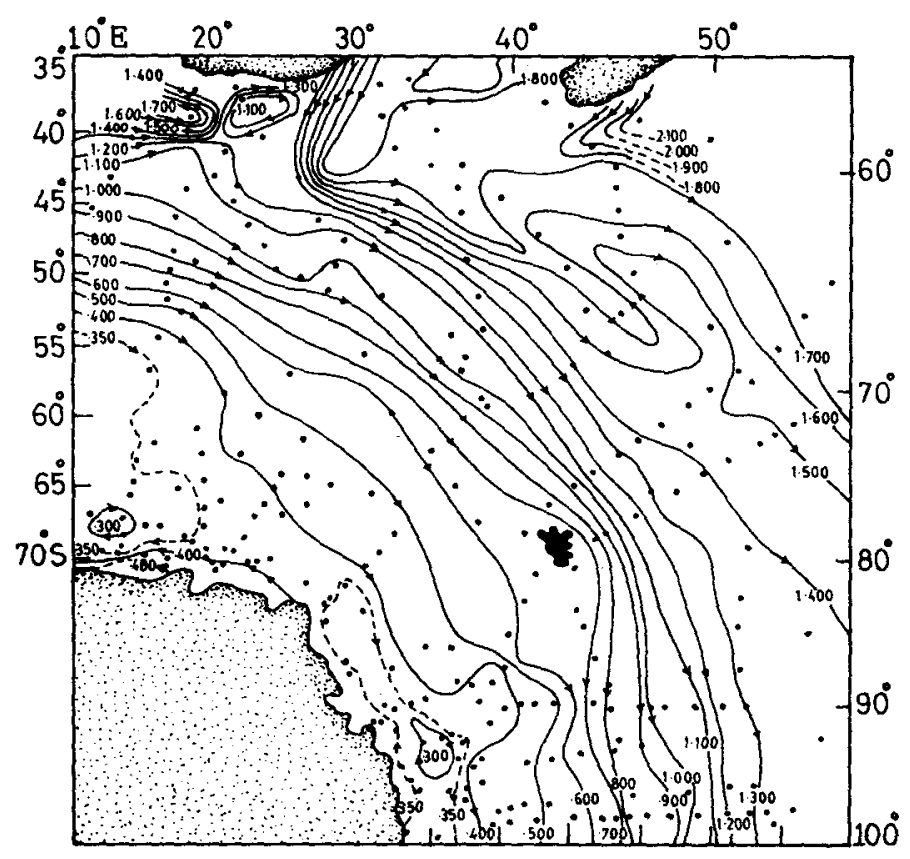

Figure 5. Dynamic topography of the sea surface with reference to $1000 \mathrm{db}$.

Within the West Wind Drift system a westerly flow between $45^{\circ} \mathrm{E}$ and $65^{\circ} \mathrm{E}$, at about $35^{\circ} \mathrm{S}$ is noticed.

\section{Discussion}

According to the vertical sections presented, the whole region under study can be divided into three zones, the extreme ends being characterized by frontal structure. The southern one is designated as the Polar Front Zone while the northern one is termed as the Sub-Antarctic Convergence Zone.

Polar Front Zone is formed near Antarctica due to intense cooling near the continent during winter. This Front is confined only to subsurface depths. Due to freezing of surface water near the continent, the salinity increases resulting in an increase of density. The denser water near the continental shelf flows to the deepermost layers and this is the Antarctic Bottom Water characterized by lower temperature, higher salinity and higher oxyty compared to the water above, which is called the Antarctic Deep Water. The coldest water which is relatively fresh spreads in the subsurface layers towards the lower latitudes. With summer heating the surface waters are warmed and they spread upto the Sub-Antarctic Zone. Such a situation gives rise to low-saline and highly oxygenated subsurface waters with temperature having extreme values below $-1^{\circ} \mathrm{C}$ and characterized by strong meridional gradients not only at the surface but extending to deeper layers. The surface water in the southern side of the convergence zone being colder, sinks to the deeper layers as a consequence of which the meridional gradients are strong. This water being fresh from the surface is characterized by lower 
salinity, and higher oxyty and is known as the Antarctic Intermediate Water. McCartney (1977) propsed that Antarctic Intermediate Water forms north of the SubAntarctic Zone primarily in the southeast Pacific Ocean where the coldest water and fresher variety of Sub-Antarctic Mode Water is transformed into Antarctic Intermediate Water. He suggested a mechanism whereby late winter heat loss to the atmosphere results in deep convection and formation of relatively homogeneous water mass, the sub-Antarctic Mode Water. Molinelli (1981) concludes that the Antarctic Intermediate Water is the composite of waters formed by late winter convection. The thermal structure in this region shows a peculiar nature of the cold water sandwiched between the warm layers above and below. This layer is called dicothermal layer (Pickard and Emery 1982) which is conspicuous only during summer (figure 4a) extending upto even $50^{\circ} \mathrm{S}$ in the western region due to relatively high salinity water of Antarctic origin whereas it is confined to south of $60^{\circ} \mathrm{S}$ in the eastern region.

The surface waters between the Polar Front Zone and the Sub-Antarctic Convergence are marked by least meridional gradients, because either surplus radiation in summer or deficit radiation in winter is used only for melting of ice or freezing of water respectively, but not to change the temperature. Nevertheless, the Sub-Antarctic Convergence Zone shifts meridionally to higher latitudes in winter and lower latitudes in summer.

The surface flow around Antarctica is mainly zonal as in the Atlantic and Pacific regions. The East Wind Drift appears as a very narrow current close to Antarctica. The boundary between the East and West Wind drifts is at a lower latitude in the eastern side of the Indian Ocean where the land extends northward compared to the western Indian Ocean. Contrary to expectations a westward flow is observed near $35^{\circ} \mathrm{S}$ between $45^{\circ} \mathrm{E}$ and $65^{\circ} \mathrm{E}$. A similar flow is also noticed around the same latitude in I.I.O.E. Atlas (Wyrtki 1971). As the data in the atlas is averaged over 5-degree-latitude-longitude quadrangle, it is not certain whether this flow is a permanent feature or not and a more detailed study is required for a clear understanding of this interesting phenomenon.

\section{Conclusions}

In the regions of dicothermal layer the velocity of sound decreases with depth and then increases. In the regions of such sound velocity structure the sound channel extends to very long distances. Further the dicothermal layer is formed in the depth range of 50 to $100 \mathrm{~m}$. The Antarctic region can be used for long distance transmission at shallow depths and this channel can even be found extended round the globe between $50^{\circ} \mathrm{S}$ and $60^{\circ} \mathrm{S}$.

In the region between the Polar Front Zone and the Sub-Antarctic Convergence Zone the meridional variation of temperature is minimum which results in the least atmospheric pressure gradients. The winds in this region are therefore expected to be relatively very weak unlike in the two frontal zones on either side of this region where strong blizzards prevail throughout the year creating operational hazards. Hence, the region between $55^{\circ} \mathrm{S}$ and $60^{\circ} \mathrm{S}$ can be used for operations and installation of energy extraction units.

The present knowledge of the hydrography and circulation off Antarctica, particularly in the Indian Ocean region is based on the meagre oceanographic data available. For a detailed study it may be necessary to carry out oceanographic survey at closure 
intervals and also systematically along the longitudes and latitudes so that the zonal as well as the meridional flow pattern can be worked out with more precision, particularly in the region of Sub-Antarctic Convergence Zone.

\section{References}

Deacon G E R 1933 Discovery Rep. 7171

Deacon G E R 1937 Discovery Rep. 151

Deacon G E R 1982 Deep Sea Res. 291

Emery W J 1977 J. Phys. Oceanogr. 7811

Georgi D T 1978 J. Geophys. Res. 834579

Georgi D T 1979 J. Phys. Oceanogr. 9456

Georgi D T 1981 J. Geophys. Res. 866566

Gordon A L 1967 Am. Geophys. Soc. Antarctica Map Folio Series: Folio 614 Plates

Gordon A L 1971a Research in the Antarctica Washington D.C. Am. Ass. Adv. Sci. 609

Gordon A L 1971b Antarctic Oceanology I Am. Geophys. Un. 15205

Gordon A L 1972 Antarctic Oceanology II Am. Geophys. Un. 1971

Gordon A L 1975 Deep Sea Res. 22355

Gordon A L 1978 J. Phys. Oceanogr. 8600

Gordon A L 1981 Deep Sea Res. 281239

Gordon A L and Tchernia P 1972 Antarctic Oceanology II Am. Geophys. Un. 1959

Gordon A L, Georgi D T and Taylor H W 1977a J. Phys. Oceanogr. 7309

Gordon A L, Georgi D T and Taylor 1977b Antarctic oceanographic zonation In Polar Oceans 45

Gordon A L, Molinelli E and Baker T 1978 J. Geophys. Res. 873023

Heath R A, Bryden and Hayers S P 1978 Antarctica J. United States 1376

Helland-Hansen B 1930 Rep. Sans N. Atl. Deep Sea Exped. 1317

Houtman Th J 1964 N.Z. Geol. Geophys. 7245

Ivanov Yu A 1961 Okeanologicheskiya Issledovaniya 330

Jacobs S S and Georgi D T 1977 In, A voyage of Discovery; Deep Sea Res. Suppl. 2443

Joyce T M, Zenck W and Toole J M 1978 J. Geophys. Res. 836093

Joyce T M, Patterson S L and Millard R C 1981 Deep Sea Res. 281265

Mackintosh N A 1946 Discovery Rep. 23177

McCartney M S 1977 Deep Sea Res. 24 (Suppl) 103

McGinnes R F 1974 Science 186736

Meinardus W 1923 Deut Sudpolar Exped. III Meteorol. 1

Molinelli E 1981 J. Mar. Res. 39267

Mosby H 1934 Scientific results of the Norwegian Antarctic expedition 1927-1928 21

Nowlin W D (Jr), Whitworth T and Pillsbury R D 1977 J. Phys. Oceanogr. 7788

Pickard G L and Emery W J 1982 Descriptive physical oceanography 4th Ed., (New York: Pergamon Press) pp. 249

Sievers H A and Emery W J 1978 J. Geophys. Res. 833010

Sciremammano F (Jr) 1979 J. Phys. Oceanogr. 9221

Sverdrup H U 1940 Antarctic Research Expedition 1921-1931, Oceanogr. III 388

Whitworth T 1980 Deep Sea Res. 27497

Wyrtki K 1971 Oceanographic Atlas of the International Indian Ocean Expedition, National Science Foundations, Washington D.C. pp. 531 